\title{
The New Managerial Challenge: Transforming Environmental and Health Issues to Competitive Advantages
}

\author{
Øystein Moen', Rikke Bramming Jørgensen²
}

\begin{abstract}
The major aim of the paper is to investigate how environmental ("green") factors may influence on international business activities and the competitiveness of firms. The paper suggests that an environmental performance lower than the industry average would represent a risk for the firm, while a performance above the industry average could result in increased cost and/or increased competitiveness. Further, it is suggested that the average environmental performance in most industries will improve, due to a situation where most firms attempt to perform better than or equal to their industry's average levels. The author present twelve specific recommendations for managers, aimed at improving firm competitiveness in international markets.
\end{abstract}

Keywords: innovation; industrial competitiveness; management; environment.

\footnotetext{
' Norwegian University of Science and Technology. Department of Industrial Economics and Technology Management. Alfred Getz vei I. 749I Trondheim-Norway. Phone: 04790 I43 103. Fax: 04773591045. Email: Oeystein.Moen@iot.ntnu.no ${ }^{2}$ Norwegian University of Science and Technology. Department of Industrial Economics and Technology Management. Alfred Getz vei I. 749I Trondheim-Norway. Phone: 0479802276I. Fax: 0477359I045. Email: Rikke.B.Joergensen@iot.ntnu.no
} 


\section{Introduction}

Development trends related to the environment (global warming, indoor and outdoor environments) may represent major challenges and opportunities for the business sector as described by Brammer, Pavelin, and Porter (2006). This is caused partly by expectations from shareholders (Buysse, Verbeke 2003; Salzmann, lonescuSomers, Steger 2005), pressure from media coverage and non-governmental organizations (Kong et al. 2002), changing consumer preferences (D'Souza et al. 2006), and new demands from industrial customers and partners (Zhu, Sarkis, Geng 2005), as well as new regulations affecting firm activities (Claver et al. 2007).

President and CEO Alan Mulally and Executive Chairman Bill Ford of the Ford Motor Company recently stated in the company's sustainability report: "These are challenging times, not only for our Company but for our planet and its inhabitants. The markets for our products are changing rapidly, and there is fierce competition everywhere we operate. Collectively, we face daunting global sustainability challenges, including climate change, depletion of natural resources, poverty, population growth, urbanization and congestion" (Mulally, Ford 2008). Most likely, they have a point, not only of relevance and importance for the car manufacturing industry, but for many other industries as well.

The main aim of the paper is to give a brief overview of research focusing the potential interaction between environmental performance and firm competitiveness, and implications for managers are presented. In this paper, the term environmental performance is used similar to the term green performance, as defined by Clemens (2006): "the degree to which firms' green effectiveness, responsiveness, conscientiousness and investment strategy are better for the environment than those of their competitors" (page 492). Even though the concept CSR is broader, research focusing CSR will be included as this is closely related to the green/environmental effect of company activities.

The paper is organized as follows: First, environmental and health issues are described, focusing on current knowledge. Second, a brief presentation of our knowledge of the economic effects of environmental performance is presented. Third, actual and expected firm behaviours are commented on, followed by a discussion about implications for managers.

\section{The Environmental and Health Dimensions: Status of Knowledge}

\section{Global Warming}

Elaborating on the issue of global warming and the possible effects thereof is unnecessary. The Intergovernmental Panel on Climate Change (IPCC) was awarded the Nobel Peace Price for 2007 together with former vice president of the United States, Al Gore. The role of IPCC is to organize and summarize research worldwide from a large number of researchers "...to assess scientific, technical and socio- economic information relevant for the understanding of climate change, its potential impacts and options for adaptation and mitigation". IPCC presented the fourth assessment report "Climate Change 2007", which represents a comprehensive and up-to-date assessment of the current state of knowledge on climate change. The IPCC reports, which are based on a large number of scientific studies, conclude that climatic changes based on human activities exist, and that these changes most likely will have considerable impact. The public and media coverage of global warming issues is extensive, not least due to the expectation that these changes will influence society, including the business sector and most types of economic activities, in a variety of ways. From a management perspective, the possible change of consumer and/or industrial customer preferences and buying behaviour caused by attention to global warming may develop into an increasingly important issue.

\section{Individual and Working Environmental Health Issues}

From the perspective of the individual, climate changes may have an impact - but other developments are also observed. It is documented a rapid increase in allergic diseases or asthma, increased occurrence of certain types of cancer, a reduced ability to reproduce in the male population and increasing levels of food intolerance among children (Howarth, 1998). The rapidness of this development indicates that genetic changes are not part of the explanation, while exposure to chemicals (at home, in the working environment, outdoor, from food etc) may be an important part of the explanation.

As a consequence, chemicals are classified in different risk groups. For example, IARC has classified chemical 
compounds that (may) have carcinogenic effects. If a particular substance (chemical) is reclassified or included in categories as "Risk phrase R45: May cause cancer", it would make it necessary for a large number of firms in different industries to engage in development processes. They would have to change product characteristics and include business partners and suppliers in adjusting to these new classifications. In the same manner as for substances with potential carcinogenic effects, substances with adverse effects on genetic material or adverse effects on the ability to reproduce have been classified in different risk levels. As above, these are substances and chemicals used in many industries, where classification changes may have substantial effects at the firm level.

From a governmental perspective, this is a development that has contributed to documentation requirements and new regulations for manufacturers. From a consumer perspective, this is a development that may result in increased attention to health factors in the buying process. From a marketing point of view, a large number of product groups exist, where a focus on different environmental and health aspects may represent an important source of disadvantage (i.e. the use of chemicals suddenly classified as carcinogenic) or a source for competitive advantage.

\section{Does "Green Performance" Influence on Competitiveness?}

A number of different arguments suggest possible negative or positive effects of an environmental focus on the firm's economic/financial performance. It should be noted at the majority of this research focus on pollution, not $\mathrm{CO}_{2}$ emissions or issues directly related to the health of individuals.

Telle (2006) raises an important question: "If improved environmental performance pays off, why do so many firms reveal a poor environmental performance?” (p. 198). Rational firms act to maximize economic performance, and Telle further states that a low environmental performance in many industries "can be regarded as indication of a negative, rather than positive, effect of environmental performance on profitability" (p. 198).

According to Telle (2006) "Traditionally, economists claim that production is optimally determined by profit maximization and hence any additional efforts to improve a firms environmental performance inevitably yield (weakly) lower profits." (p. 195). As improved environmental performance may involve different cost increases such as identifying options, capital allocation and investments, increased operation costs, and shifts in R\&D focus, the arguments for a negative association are significant (Jaffe, Stavins, 1995),

But other arguments are also presented, stating a potentially positive effect. For example, one can expect to see a positive performance effect of environmental concerns based on increased employee motivation, improved energy efficiency, or higher market shares (Porter, van der Linde 1995; Reinhardt 1999;). Basically, the arguments focus either on cost reduction (energy savings, waste reduction, packaging costs, reduced insurance costs, etc.) or on increased revenues (Bonifant, Arnold, Long 1995; Filbeck, Gorman 2004; Porter 1991). These increased revenues may be due to factors such as a more competent and motivated work force or improved company image, strengthening the company's market position.

A number of quantitative empirical studies have investigated the relationship between environmental performance and different measures of economic and financial performance; overviews are presented by McGuire, Sundgren, Schneeweis (1998) and Wagner (2005). With different theoretical and empirical approaches, the results are generally mixed, based on stock market indices (Erfle, Fratantuono, 1992; White 1991), pollution control records (Karpoff, Lott, Wehrly, 2005), or media coverage of positive or negative environmental/firm issues on market value (Hamilton 1995; King, Lenox, 2002; Russo, Fouts, 1997). Some of these studies identify positive direct effects, as represented by Hart, Ahuja (1996). However, this is a complex issue. Clemens (2006) identifies a positive correlation between environmental and economic performance, but questions the existence of a causal link. When he controlled for plant characteristics, the positive effect dissolved. This indicates that other factors as management skills and technology levels may influence both on environmental and economic performance.

Even though Ungson, James, Spicer (1985) states that there is a common expectation for green issues to be 
negative for performance, recent literature suggest that this is not necessarily the case for large firms. A number of possible explanations exist, including a better ability to predict regulatory changes (Christmann, 2000) and a superior ability to use interdisciplinary competence (toxicology, testing, etc.) in large firms compared to small firms (Clemens, 2006). Large firms may also use portfolio management to build competitive advantages through the use of relevant environmental resources (Bansal, 2005; Clemens, 2006). Considering small firms in his broad review of the literature, (Clemens, 2006) only identified two studies of green incentives and financial performance, and these even showed contradictory results.

The confusion may be exemplified by Derwall et al. (2004) who stated: "There exists a widespread consensus among mainstream academics and investors that socially responsible investing (SRI) leads to inferior, rather than superior, portfolio performance" (Derwall et al., 2004, page I) but based on the empirical results presented in the paper they concluded: "Overall, we find that companies performing relatively well along environmental dimensions collectively provide superior returns" Derwall et al. (2004, page 15). A different story is presented by Portney (2008) who states that the Vice Fund have been among the most profitable of all US investments funds between 2003 and 2006, only investing in companies with a low or very low CSR-standing.

Nelling and Webb (2006) showed that if using a simple regression approach, CSR performance and financial performance was related. But when more advanced statistical methods and control variables were included, this relation disappeared. They further question the direction of the causality. If a correlation between CSRperformance and financial performance does exist, it might just as well be caused by a situation where companies with a strong financial performance as a consequence may be able to improve their CSRperformance.

In summary, traditional theoretical arguments presented by economists have indicated a negative influence of environmental performance on financial performance, but empirical results are mixed. Scholars focusing on competitive advantages within the management literature have argued that environmental performance might provide a source for competitiveness (Hoffman, 2000;
King, Lenox, 2002; Porter, 1991) and some have even argued that there is a difference between small and large firms.

Based on existing literature, it is not possible draw any conclusions with regard to a possible positive or negative effect of environmental performance on economic/financial performance, a conclusion also supported by Crane (2008): "Empirical researchers have been [...] unable to agree on the answer to the one question that has dominated CSR research probably more than any other over the past 30 years, which is whether CSR is good for business or not".

It should be noted that much of the existing research has significant limitations. First, with a few exceptions, very limited evidence exists of the possible complex interaction between important groups of variables that might have an effect on the conclusions. Second, broad, cross-industry investigations based on large listed firms will often have limitations in regard to identify real business decisions and processes, including the impact of environmental performance. Third, most of the studies investigating the relation between environmental concerns and economic performance use different measures of outdoor pollution as an indicator of environmental performance. Issues and factors related to global warming or consumer-related issues, such as indoor environment/asthma/allergic diseases are not included. Finally, it seem as few of the studies presented focusing green performance/CSR use firm level surveys and advanced statistical analyses. In example, very few studies use structural equations modelling approaches (SEM) which is more or less expected in other management related research areas.

From a management perspective, it could seem as the risk-reducing behaviour to pursue would be to keep close to the industrial average with regard to environmental performance. Above average could imply increased costs, whereas below average could result in market reactions and perceived increased risk from an investor perspective. However, new developments related to $\mathrm{CO}_{2}$ emissions (global warming) or governmental regulations might influence the decisions made, increasing the complexity in defining the most suited future strategies for firms. 


\section{Actual and Expected Firm Behaviour}

Even though there are many unknowns concerning the effect of environmental performance on economic performance, it seems that many companies, at least officially, increasingly pay attention to the environmental aspects related to their activities - an examination of firm home pages illustrates this situation:

Siemens: "Driven by a strong commitment to sound environmental practices, we engage in a wide range of initiatives and programs all over the world and pursue $a$ cradle-to-grave approach to product stewardship that aims to reduce environmental impacts across the entire product lifecycle" (Siemens, 2008).

ABB: "Sustainability is integral to all aspects of our business. We strive to balance economic, environmental and social objectives and integrate them into our daily business decisions" (ABB, 2008).

Hewlett Packard: "As an industry leader, HP has set aggressive goals to reduce the environmental impact of our operations and products" (Hewlett Packard, 2008).

Presenting statements in company publications and on web pages is easy, actions prove whether these statements actually reflect a real commitment. The questions arise; why do so many firms state and express so much attention to sustainability and environmental factors? A number of different explanations may exist, including:

First, shareholders are more and more actively paying attention to environmentally-related aspects. For example, 13 of the largest and most important capital funds, such as Fidelity, AXA IM, Wellington, and TIAA met for two days in 2007, discussing how to influence the environmental strategies and behaviours of the firms they invested in (DN, 2007). Some of these investor groups exit or terminate investments where the environmental performances of a firm are found unsatisfactory, including requesting meetings with top level managers if a company is regarded as delivering weak environmental results. There is no doubt that shareholders are influencing firm behaviour within these dimensions, which is indicative of an economic rationale for avoiding falling far below the average or acceptable industry standards.
Second, activities of non-governmental organizations (NGOs), press coverage, and company reputation are highly interrelated aspects. NGOs may target firms whose actions and priorities are deemed to have a negative impact on the environment. Such actions may influence both the overall reputation of the firm and stimulate to greater management focus on environmentally-related issues. For example, independent groups like Wal-Mart Watch have been established. According to the group's web pages: “In Spring 2005, Wal-Mart Watch began a nationwide public education campaign to challenge the world's largest retailer, Wal-Mart, to become a better employer, neighbor, and corporate citizen .Wal-Mart Watch aggressively tells a new, more truthful WalMart story"(Wal-Mart Watch, 2008). It seems reasonable to expect that the combined effect of investor expectations and NGO campaigns may have considerable impact on firm behavior.

Third, environmental performance may influence consumer intentions and behaviours. Limited evidence exists, but some studies suggest that consumers state they would choose environmentally friendly products (intentions and attitudes), but that the actual buying actions do not reflect these intentions (Mainieri et al. 1997). It has been suggested that consumers do not believe that their actions on the individual level have significant impact and that they regard arguments from the industry as a means either to promote inferior products or to increase prices without increasing quality, combined with a tendency to social over-reporting of environmental concern (Peattie, 200I). It seems that most marketing campaigns promoting a product as being better than its competitors with regard to reduced $\mathrm{CO}_{2}$ emissions or pollution are not successful. Even though it does not seem as consumers give much attention to environmental aspects when making purchase decisions now, most producers seem to be uncertain about future developments. If consumer behaviour changes, it would be extremely difficult to adjust if the company's competitors already had made major efforts over a long period of time. Thus, the risk of exposing a future competitive weakness may motivate firms to emphasise environmental issues.

Fourth, established and expected new regulations affecting businesses, as exemplified by the California State regulation of $\mathrm{CO}_{2}$ emissions from vehicles and demands 
for a percentage of cars based on alternative fuel systems. New regulations, standards, and various labelling systems with an environmental focus may make it necessary for many firms to increase their attention to environmental issues.

Fifth, as most businesses are involved in complex business networks, it is evident than partners, suppliers and customers may demand awareness of environmental issues, as described by Hakansson and Waluszewski (2002). When competing with other firms and collaborating with partners, it may prove to be a disadvantage if a firm does not deliver in these aspects.

Sixth, it may actually be possible to develop competitive advantages based on improved green performance. Even this is not a general suitable strategy, there may exist opportunities for specific firms to create advantages that makes it possible to be more competitive.

As a consequence, an important development may be that an industry's average environmental performance (at least for some industries) is improving, due to a situation where many firms act in order not to perform below average. This development creates a need for both innovation and improvement in order to maintain competitiveness. It may be argued that consistent improvement of environmental performance is necessary to maintain a firm's economic and financial performance.

Limited evidence exists as to the actions taken by firms to handle these challenges, and the next sections present illustrative stories in order to provide some insight into priorities and actions of firms facing environmental and health-related opportunities and challenges.

\section{Illustrative Stories}

In order to examine the developments that might take place, three brief stories will be presented. The first describe how new regulatory schemes and market demands drive product development processes in the paint industry. The second story show how Ford Motor Company has paid attention both to the issue of global warming and to emissions and individual health effects. The third story illustrates how a new environmental related tax scheme (NOx) in Norway was developed.

\section{The Manufacturer of Paint}

When examining the producer of paint, it became evident that an ambition of reducing $\mathrm{CO}_{2}$ emissions had resulted in some adjustments of activities and that the producer systematically tried to reduce environmental impacts of its production processes. But the primary concern involved two closely related issues: First, the need to adjust products to comply with new labelling schemes and governmental regulations in a variety of countries, and second, ambitions to increase profitability and consumer market competitiveness through superior products having reduced emissions (less negative impact on the environment).

New EU regulations introduce guidelines banning oilbased paints from 2010. For all producers, this has resulted in a need for extensive product development processes. Moreover, some producers systematically market consumer products as being environmental friendly with documented low rates of emission. Producers unable to develop quality products and production processes that satisfy the new EU regulations will be unable to compete in the European market as of 2010. Even the pressure to develop better quality (lowemission) products seems to significantly change the competitiveness of different firms.

From the perspective of a producer of paints operating in international markets, the existence of diverse and complex product testing schemes and labelling systems has a direct impact on their competitiveness in different markets. Examples of such schemes are AgBB, GuT and EMICODE in Germany, MI in Finland, the Danish Indoor Climate Labelling Scheme, Natureplus in several countries, CECAT in France and Ecolabel in Austria. If a producer do not meet the demands and specifications from different mass-market oriented labelling schemes they will have a serious marketing challenge in the consumer markets. Not only end-customers, but also distributors and retailers will most likely prefer suppliers satisfying the specifications and requirements from the most profiled and well-known labelling schemes when they make business decisions. Due to cross-national regulations they may also be excluded from markets if they do not match new regulations (in example EUguidelines). If they do not meet requirements from particular groups of customers, such as car manufacturers 
or producers of floor or building products; they are unable to compete and deliver their paints to these customers.

An important fact should be noted: paint manufacturers do not use substances with negative effects on the environment without good reason. Eliminating or reducing the amount of particular chemicals might reduce other aspects of product quality (ease of painting, visual quality, amount of paint needed to cover a surface, life-time of paint, etc.) as well as production costs.

From a management perspective, a key issue is standardisation versus differentiation. Production cost differences, a need for process development, national differences in consumer preferences, product development costs, and the variety of labelling schemes have made managing international operations increasingly more complex and challenging not least concerning the ability to offer standardised products in a number of markets.

It seems reasonable to state that the development with regards to environmental issues (emissions and labelling schemes) are extremely important factors influencing both market decisions and the company's competitiveness.

\section{Ford Motor Company}

An examination of the company's web pages and various other publications establishes a strong focus on several different dimensions of environmental and health effects, including global warming, pollution, and individual (customer) health effects.

As regards global warming, Ford highlights and stresses their decisive actions aimed at reducing $\mathrm{CO}_{2}$ emissions from their activities, as well as other negative influences on the environment. A specific report gives detailed information on actions taken and the company's ambitions for further improvement: "Specifically, the Ford Report on the Business Impact of Climate Change addresses how concerns about emissions of greenhouse gases, including carbon dioxide, are linked to other factors affecting the business; the steps the company is taking to manage the risks and capture opportunities associated with climate change; and the market, policy, social and technological enablers required to achieve significant changes in the industry's carbon footprint" (Ford, 2008a). This response is in part caused by a pressure from shareholders and investors, as well as from NGO campaigns. It should be noted that Ford does present detailed plans of action and monitoring reports assessing the results obtained with the objective of reducing $\mathrm{CO}_{2}$ emissions from their worldwide activities.

Ford also focuses on pollution and on reducing the negative impact of chemical effects on the environment, for example with regard to the paints used, as demonstrated with the below citations from (Ford 2008b):

\section{"A Greener Way to Paint Vehicles}

Painting vehicles has traditionally been one of the auto industry's biggest environmental challenges. However, we've found an environmentally sound, cost-efficient solution that produces beautifully painted vehicles with long-term durability.

\section{An Industry First}

We're working with U-Haul to put on the road the industry's first fleet of vehicles painted with Ford's environmentally responsible new technology, which produces 15 percent fewer greenhouse gases than the traditional method and cuts Ford's production costs.

\section{Benefits}

In addition to reduced $\mathrm{CO} 2$ emissions, the new technology reduces volatile organic compounds (VOC) emissions by about 10 percent. We estimate we can save approximately $\$ 7$ per vehicle by cutting the time it takes to paint a vehicle by almost 20 percent as well as reducing the size of the traditional paint shop by nearly 15 percent.

\section{A Greener Process}

Our new high-solids, solvent-borne paint formulation produces fewer VOC and CO2 emissions than do water-borne and current solvent-borne paints. Because the new formulation contains more colour pigment, it requires less paint to cover a vehicle than water-based paint."

As indicated, Ford has made changes both with regard to the painting process and the specific characteristics of the paints used. This is an example of an improvement process that most likely included close collaboration with both paint suppliers and suppliers of painting process equipment. In addition to allocating resources to the development process, these partners also need to demonstrate a certain 
capacity for innovation. From the perspective of the Ford Motor Company, selecting partners with this kind of capacity for innovation will be highly important in order to be successful in the company's efforts to increase competitiveness.

Often, large suppliers may be included in integrated product development processes. From the perspective of Ford and other manufacturers within the automotive industry, they will seek out suppliers that are able to meet their needs both in terms of improvements in $\mathrm{CO}_{2}$ emissions and in terms of reduced emissions of VOCs and other substances. These partners and suppliers will face new challenges with regard to documentation and innovation capabilities.

\section{Development of the NOx Taxation Scheme}

Norway established the NOx taxation scheme in January 2007. As a consequence, most vessels operating in Norwegian waters had to pay a tax of 15.39 NOK per kilo NOx emitted (increased to $15.85 \mathrm{NOK}$ from 2009). A NOx fund is established, were members may use revenues generated to NOx-reduction investments.

Sweden has developed a slightly different model, establishing a REP-taxation system (Refunded Emission Payment) with some important advantages: "The innovative design of the REP presents many advantages over traditional instruments... One benefit of combining a tax with a refund is its political economy. Although the abatement incentives are the same as for a tax of the same value, polluters are less averse to the REP scheme, and thus potential resistance is defused and lobbing from the polluters is reduced. Refunded emission payments are politically easier to implement at a sufficiently high charge level to yield significant abatement effects... since the monetary flows from the pool of polluters are redistributed within the same system, the REP causes very little competitive loss for the targeted group as a whole. This is an important feature for a policymaker wanting to implement a policy in one small, open economy”. (Sterner, Turnheim, 2008, page 10). As stated above, the effect for the group or industry may be limited, but this is not the case for each involved company: "The REP mechanism rewards the combustion units that reduce their emission intensities to lower-than-average levels. For units with average emission intensity, the charge and refund will be equal, and hence there is no net payment. The units with the lowest emission intensities (emissions per useful energy produced) become net beneficiaries of the system, whereas those with higher-than-average emission intensities make a net payment”. (Sterner, Turnheim, 2008, p.10). Denmark will introduce a NOx scheme in 2010, with lower rates than Sweden, it must be expected that other countries follows.

Even though these taxation schemes with refunds influence on the involved NOx producing activities, the real winners are companies offering equipment of systems able to reduce NOx emissions. This is an example of a development were governmental initiatives create opportunities were firms may position their activity in order to increase their competitiveness. It should be noted that $\mathrm{NHO}$ is actively lobbying the Norwegian government to establish a CO2 fund based on a REP-model, and it seem likely that for a number of emission areas this type of models will be used across different industries and countries. As a consequence, this new types of regulations must be expected to reward companies with green performance better than industrial average and increase costs for firms performing below average.

A particular interesting part of the establishment of the Norwegian NOx taxation scheme is the process. Riksrevisjonen (the office of the Audit General of Norway) has presented surprisingly hard criticism of the ground work and the lack of analysis of the consequences. They state that all involved ministries (Finance; Trade and Industry; Transport and Communication; Environment) most likely have failed to behave in accordance to the normal requirements when establishing new laws and regulations as defined by the Parliament (Riksrevisjonen, 2008). It should further be noted that most of the existing documentation is defined as confidential and not open for external evaluation.

\section{Discussion and Concluding Remarks}

In this section implications for managers are commented. Finally, some concluding remarks will be made.

\section{The Challenge?}

The three case stories presented illustrate how environmental and health related issues may influence business decisions and strategies both from the perspective of a car manufacturer, the maritime industry and producers of paints. As indicated, the business-tobusiness market is also heavily influenced, as new priorities and needs affect the selection of partners/suppliers and

ISSN: 07I 8-2724. (http://www.jotmi.org)

Journal of Technology Management \& Innovation (C) Universidad Alberto Hurtado, Facultad de Economía y Negocios 
shape new demands placed on business partners. For the case from the paint industry in particular, these aspects are key elements in understanding competitiveness and international marketing strategies. The questions are obvious: Is the paint industry just an example of an industry with different characteristics than most industries - or may it serve as an example of a development with considerable significance for many other business sectors as well? Is the Ford Motor Company an exception from the norm in the automotive industry, or will most companies in this industry increasingly begin to focus on $\mathrm{CO}_{2}$ emissions, pollution, and individual health issues? Is the NOx taxation scheme a unique story, or a indication of a broader development?

A snapshot from other industries illustrates related challenges there as well: In our university laboratories we observe how the furniture manufacturing industry is currently faced with new standards and now have begun testing for emissions from new products in order to reduce the potentially adverse effects of their products and from their production processes, both on the indoor and outdoor environment. In the media we read about how manufactures of food are required to document the farm of origin for meat and present detailed information about the content of their products. The toy manufacturer Mattel/Fisher-Price recently experienced that the lead content of some of their toys, which was above the recommended level, was defined as toxic and a significant range of products had to be recalled from the market. It seems reasonable to expect that for most sectors or industries, either $\mathrm{CO}_{2} /$ global warming, other forms of outdoor pollution, or individual health considerations may play an increasingly important role.

The manager challenge - is it possible to develop new competitive advantages?

Evaluating the literature, two major conclusions is evident. First, focusing CSR or green performance has no direct and positive effect on performance in general. Second, specific firms may use specific environmental related initiatives to improve their competitiveness. Following Lazzlo, Sherman et al. (2006), it seem as environmental issues may be described as a untapped source of advantage which may be more important in the future. As stated by Zhu, Sarkis et al. (2005): “...environmental items may provide new opportunities for competition” (page 450).
As indicated above, very limited scientific evidence yet exists, making it difficult to give managers advice based on research. However, we would like to offer some advice that managers ought to consider:

I) Analyse the changes taking place within your industry

When top-level managers of the Ford Motor Company claim that they are facing significant challenges in their industry, managers in many other industries may be in similar situations as well. It is our advice that the developments should be evaluated, including $\mathrm{CO}_{2}$ emissions, outdoor pollution, and individual health issues. Factors such as end user/customer demands, value chain activities and supplier relations, NGO activities and potential media attention, and changes in public policy, regulations, and labelling schemes, as well as owner/stakeholder expectations and competitor actions, should be addressed. Based on a systematic evaluation, firms should identify weaknesses and potential threats and the potential for development of competitive advantages.

2) Improve environmental and health related performance

It is reasonable to expect that many firms will conclude that they have to perform better than or equal to the industry average in terms of environmental performance within their line of business. As a consequence, the average performance may be expected to improve, and for some sectors this might be a rapid development. Neglecting to develop its environmental performance will represent an increasingly greater risk for the firm. Establishing benchmarch procedures that measure firm performance compared to the industrial average is recommended.

3) Develop documentation, verification, and testing capabilities

Suppliers, partners, customers, public demands in form of laws and regulations, labelling schemes, etc. - in many industries the need for and attention paid to documentation of product specifications, and also often external verification of these characteristics, will increase. Many firms will need to develop internal capabilities, and/or to build relationships with R\&D institutions and other external partners with access to testing facilities. Identifying potential partners and establishing cooperation, for example with universities or research foundations with 
the necessary expertise may become more important. Such partners may be a potential source of improved performance and competitiveness, not least by providing access to suitable laboratory facilities and for providing the capacity/expertise to test the products and participate in product development processes.

\section{4) Be aware of the window of opportunity}

When consumer or customer preferences change, or when new standards or regulations emerge - a window of opportunity may open up for a limited time only. Some firms may be able to react rapidly and take advantage of such opportunities. The firm ought to decide whether there seems to exist any first-mover opportunities that could increase competitiveness. It is possible to evaluate the timing of these new product lines presented by different manufacturers, from the first who take advantage of an opportunity to the late follower who is mainly fixing a market disadvantage.

\section{5) Do not forget the individual health perspective}

In the media, much attention is currently being paid to global warming, and $\mathrm{CO}_{2}$ emissions, whereas outdoor pollution has had attention for a long period of time. The individual health perspective may have a stronger impact for a variety of consumer products, for firms operating in the value chain delivering consumer products or products with impact on the working environment. With a wealthy and ageing population, as is the case in many western countries, it may very well be that the importance of individual health will be even more important in the years to come. For some firms, opportunities for increased competitiveness might be found in relation to individual health considerations.

\section{6) Be part of the winning industrial networks}

Many firms have close ties to suppliers and customers. Within and between industrial networks environmental performance may vary, and in order to strengthen the company's competitive positions both suppliers and customers should be carefully evaluated on environmental performance as well. If both suppliers and industrial customers are able to present verified product specifications and to pay attention to environmental and health issues the firm reduces the risk of operating in a low-performing industrial network. It should be noted that this is more than an evaluation of suppliers; if a firm's industrial customers are losing competitiveness due to poor environmental performances, this will have consequences for future revenues.

7) It will be increasingly difficult to reduce costs by outsourcing poor environmental performance

One of the reasons firms outsource activities has been to reduce costs. In some industries, lower costs in certain countries have been related to lower environmental requirements or health standards, both in the form of public regulations and the environmental profiles of partners. Recent studies from China, for example, suggest that Chinese enterprises have increased their environmental awareness due to regulatory, competitive, and marketing pressures (Zhu et al. 2005). And there are examples of how media coverage and NGOs attention impact the environmental performance of foreign suppliers as well, targeting firms that use low-performing suppliers. As a consequence, the outsourcing of activities is likely to have to be managed and organized with increased emphasis on environmental and health issues as well.

8) Be careful with regard to marketing the firms as environmentally superior

In a interesting article Lyon and Maxwell (2008) describe how BP (marketing itself as high performing on CSR-issues) got more negative CSR attention related to NGO-activity than American ExxonMobil (with low attention to CSRissues). It seem as companies should be careful when they want to profile their entire organization and activity as high performing on CSR/environmental issues. This may result in three different sets of problems. First, if they experience negative incidents (in example pollution episodes) the critique may be even more loud and harming. Second, they may be more exposed to NGO-campaigns ("with your profile, you should not do..."). Third, customers may suppose that the firm has increased its cost without increasing the quality in a comparable manner.

9) Focusing CSR/green performance is only a suitable strategy for the most innovative firms

One of the few articles presented building on a structural equations modelling approach have been presented by Luo and Bhattacharya (2006) in Journal of Marketing. The results the presented are convincing, stating that innovative 
firms offering high quality products increased their market value through focus on CSR/green performance. But they also identified that companies with limited innovative capacity and low product quality could damage their position if signalling strong attention to CSR: "firms that are less innovative in meeting customer needs may send a negative signal of incorrect strategic choice and misguided firm priorities in the market that contaminates and degrades this legitimacy" (Luo, Bhattacharya, 2006, page 15). In conclusion, a firm with quality challenges perceived by its customers, may further weaken their position if they market and communicate strong CSR-performance as a important firm strategy.

10) Remember the concept of "perceived winners"

One of the most fascination concepts in management research is the related to "perceived winners". In most industries, a limited number of companies are able to be perceived as most innovative and most competitive, these companies are perceived as the future winners within the industry. Many positive effects arise from such a position, in relation to both to existing and new customers as well as related to the opportunity for developing new external networks. In order to reach such a position, a firm have to satisfactory on a number of dimensions. In addition, they need to deliver superior to most competitors in other dimensions (which dimensions varies between industries). It is possible that green performance/CSR-issues are so important that a low performance will make it impossible for a firm to be defined as a perceived winner within the industry.

II) Monitor research results within technology and new taxation initiatives

Within the paints industry, the EU ban of oil-based products from 2010 was a decision based on a long processes and discussions. Every producer had the opportunity to start responding to this possibly decision several years before it was made. In many sectors, scientific research results may define the development of labelling schemes and publicly defined standards and requirements, and through media coverage such results may influence market preferences. For some firms, it would be relevant to establish a system monitoring research results in order to be able to adjust their activity more rapidly than competitors. If strong scientific evidence were to be presented, using different test protocols that all point in a particular direction, governmental regulation must be expected to undergo adjustments, potentially affecting entire industries.

It seems obvious that both managers and investors within particular industrial sectors ought to assess whether there are specific areas of research with a potential impact on regulations and product competitiveness. In addition new taxation initiatives as the establishment of NOx taxation schemes in Norway, Sweden and Denmark may influence customer preferences. A number of such governmental initiatives exist and should be evaluated in search for opportunities. Even though regulations may be important, it should be noted that the political process and decisions may be unclear and that documentation may be limited. It must be expected that the most well-informed firms will be in better position to take advantage of new regulation and taxation initiatives.

12) It is all about creating specific competitive advantages

A general focus on green performance or CSR does not improve the firm competitiveness and performance, beyond the "keeping close to industrial average dimension". The important process is the specific search for situations were the firm may deliver value to customers related to environmental performance. The superior position will be were new governmental regulations and market demand pulls in the same direction (in example related to reduced fuel consumption/energy use). For the firm, being able to position its products and services in such positions will be valuable, but this should not be mixed with more unclear initiatives to increase "green performance".

\section{Concluding Remarks}

Environmental performance is just another factor that may be used in order to develop competitiveness, but it must be analyzed within the perspective of value for the customers. It has a particular characteristic, the strong relation to taxes, regulations and public policy.

It should be noted that policies and regulations are not independent from national economic interests, political considerations, and voter group influences. The process resulting in the Norwegian NOx taxation system has been heavily criticized by Riksrevisjonen, but similar processes must be expected also in the future. These elements have

ISSN: 07I8-2724. (http://www.jotmi.org)

Journal of Technology Management \& Innovation () Universidad Alberto Hurtado, Facultad de Economía y Negocios 
always been part of the external factors influencing firms operating in international markets. For managers, the developments observed may represent both challenges and opportunities in terms of increasing competitiveness. But an important part of the regulations established in the future will be awarding "green performance" and increased costs for low-performing firms.

Evaluating CSR/green performance research, a number of suggestions for management are presented. The major conclusion is that CSR/green performance must be expected to be improved in most industries, and that firms that perform weak in these dimensions will weaken their competitiveness compared to other firms in the industry.

\section{Reference}

ABB (2008). Welcome to Sustainability at ABB. http://www.abb.com/cawp/abbzh258/235c6a4c193429f3cl2 569680050e09f.aspx (Accessed June 6, 2008)

BANSAL, P. (2005). Evolving sustainably: A longitudinal study of corporate sustainable development. Strategic Management Journal, 26(3), pp. 197-218.

BONIFANT, B. C., Matthew B. A., Frederick J. L. (1995), Gaining competitive advantage through environmental investments. Business Horizons, 38(4), pp. 37.

BRAMMER, S. J., Stephen P., Lynda A. P. (2006), Corporate social performance and geographical diversification. Journal of Business Research, 59(9), pp. 1025.

BUYSSE, K., Verbeke, A. (2003). Proactive environmental strategies: A stakeholder management perspective. Strategic Management Journal, 24(5), pp. 453-70.

CHRISTMANN, P. (2000). Effects of "best practices" of environmental management on cost advantage: The role of complementary assets. Academy of Management Journal, 43(4), pp. 663-80.

CLAVER, E., Lopez, M. D., Molina, J. F., Tari J.J. (2007), Environmental management and firm performance: $A$ case study. Journal of Environmental Management, 84, pp. 606-19.

CLEMENS, B. (2006). Economic incentives and small firms: Does it pay to be green? Journal of Business Research, 59(4), Pp. 492-500.
D'SOUZA, C., Taghian M., Lamb P., Peretiatkos R. (2006), Green products and corporate strategy: an empirical investigation. Society and Business Review, I (2), pp. I44-57.

DN (2007). Disse menneskene kontrollerer verdier for 23.000.000.000.000 kr. Nå vil de forandre verden, generalforsamling for generalforsamling. Dagens Næringsliv 3./4. November 2007 (In Norwegian)

ERFLE, S., Fratantuono M.J. (1992), Interrelations Among Corporate Social Performance, Social Disclosure, and Financial Performance: An Empirical Investigation. Dickinson College.

FILBECK, G., Gorman, R.F. (2004). The Relationship between the Environmental and Financial Performance of Public Utilities. Environmental and Resource Economics, 29(2), Pp. 137-57.

FORD (2008). Climate Change Report http://www.ford. com/about-ford/news-announcements/press-releases/

press-releases-detail/global-climate-change-456p. (Accessed June 6,2007 )

FORD (2008b). A Greener Way to Paint Vehicles http://www.ford.com/innovation/environmentally-friendly/ corporate-sustainability/greener-vehicle-paint/ environmentally-friendly-painting-38Ip. (Accessed June 6, 2007)

HAKANSSON, H., Waluszewski, A. (2002). Path dependence: restricting or facilitating technical development? Journal of Business Research, 55(7), PP. 56I70.

HAMILTON, J.T. (1995). Pollution as News: Media and Stock Market Reactions to the Toxics Release Inventory Data. Journal of Environmental Economics and Management, 28(I), pp. 98-1 I3.

HART, S.L., Ahuja, G. (1996). Does it Pay to be Green? An Empirical Examination of the Relationship Between Emission Reduction and Firm Performance. Business Strategy and the Environment, 5(I), Pp. 30-7.

HEWART PACKETT (2008). HP Eco Solutions. http://www.hp.com/hpinfo/globalcitizenship/environment/

(Accessed June 6, 2007) 
HOFFMAN, A.J. (2000). Integrating environmental and social issues into corporate practice. Environment, 42(5), pp. 22-33.

INTERGOVERNMENTAL PANEL OF CLIMATE CHANGES (2007). Workgroup II Climate Change Impacts, adaption and vulnerability. http://www.ipcc-wg2.org/ (Accessed June 6, 2007)

JAFFE, A. B., Stavins, R. N. (1995). Dynamic Incentives of Environmental-Regulations - the Effects of Alternative Policy Instruments on Technology Diffusion. Journal of Environmental Economics and Management, 29(3), S43-S63.

KARPOFF, J.M., Lott, J.R., Wehrly, E.W. (2005). The reputational penalties for environmental violations: Empirical evidence. Journal of Law \& Economics, 48(2), pp. 653-75.

KING, A., Lenox, M. (2002). Exploring the locus of profitable pollution reduction. Management Science, 48(2), pp. 289-99.

KONG, N., Salzmann, O., Steger, U., lonescu-Somers, A. (2002). Moving business/industry towards sustainable consumption: The role of NGOs. European Management Journal, 20(2), pp. 109-27.

MAINIERI, T., Barnett, E.G. (1997). Green Buying: The influence of environmental concern on consumer behaviour. The Journal of Social Psychology, April, Pp. 189205.

MCGUIRE, J.B., Sundgren, A., Schneeweis, T. (1998). Corporate Social Responsibility and Firm Financial Performance. Academy of Management Journal, 3I (4), PP. 854-72.

MULALLY, A., Ford, B. (2008). Ford Motor Company's 2006/2007 Sustainability Report: For a More Sustainably Future. Ford Motor Company, pp. I-42.

PEATTIE, K. (200I). Towards Sustainability; The Third Age of Green Marketing. The Marketing Review, 2(2), pp. $129-46$.

PORTER, M.E., van der Linde, C. (1995). Toward a New Conception of the environment-competitiveness relationship. The Journal of Economic Perspectives (19861998), 9(4), pp. 97.
PORTER, M. (1991). Towards a Dynamic Theory of Strategy. Strategic Management Journal, 12, pp. 95-I 17.

REINHARDT, F. (1999). Market Failure and the Environmental Policies of Firms: Economic Rationales for "Beyond Compliance" Behavior. Journal of Industrial Ecology, 3(I), pp. 9-2I.

RUSSO, M.V., Fouts, P.A. (1997). A Resource-Based Perspective on Corporate Environmental Performance and Profitability. The Academy of Management Journal, 40(3), Pp. 534-59.

SALZMANN, O., lonescu-Somers, A., Steger, U. (2005). The Business Case for Corporate Sustainability:: Literature Review and Research Options. European Management Journal, 23(I), pp. 27.

SIEMENS (2008). Responsibility Performance. http://wl.siemens.com/responsibility/en/responsibility perf ormance/environmental protection/index.htm (Accessed June 6, 2008)

TELLE, K. (2006). "It pays to be green" - A premature conclusion? Environmental \& Resource Economics, 35(3), pp. 195-220.

UNGSON, G.R., James, C., Spicer, B.H. (1985). The Effects of Regulatory Agencies on Organizations in Wood Products and High Technology Electronics Industries. Academy of Management Journal, 28(2), pp. 426-45.

WAGNER, M. (2005). How to reconcile environmental and economic performance to improve corporate sustainability: corporate environmental strategies in the European paper industry. Journal of Environmental Management, 73, pp. 105-18.

WALL-MART WACH (2008). About Wall-Mart Watch. http://walmartwatch.com/about (Accessed June 6, 2007)

WHITE, M.A. (1991). Green Investing: The Recent Performance of Environmentally-Oriented Mutual Funds. McIntire School of Commerce, University of Virginia.

ZHU, Q., Sarkis, J., Geng, Y. (2005). Green supply chain management in China: pressures, practices and performance. International Journal of Operations \& Production Management, 25(5), pp. 449-68. 